\title{
ANALISIS MORFOMETRIK UKURAN TUBUH KAMBING LOKAL UMUR PRA SAPIH YANG DI PELIHARA SECARA TRADISIONAL
}

\author{
Morphometric Analysis of Body Size Local Goat In Pre Weaning Age \\ of Traditionally Maintained
}

Karsum Y Tagoi ${ }^{* 1)}$, Fahrul Ilham², Nibras K Laya ${ }^{2}$

1. Alumni Fakultas Pertanian Universitas Negeri Gorontalo

2. Jurusan Peternakan Fakultas Pertanian Universitas Negeri Gorontalo

Corresponding Author: Email: karsumtagoi15@gmail.com

\begin{abstract}
This study aims to determine body size and body size of pre-age old goat breeds traditionally maintained in Kabila Bone District, Bone Bolango District, and to find out the local goat maintenance system applied by farmers in Kabila Bone District, Bone Bolango District. The research material was local goat aged preage from 1 week to 10 weeks as many as 30 individuals. This study used a survey method. Retrieval of data by purposive sampling and sample determination by accidental sampling. The data obtained were analyzed by calculating the mean, standard deviation, coefficient of variation, regression equation, and growth rate between age and body size. Based on the statistical results, the average value obtained was $8.62 \mathrm{~cm}$ head length, $6.92 \mathrm{~cm}$ head width, $9.47 \mathrm{~cm}$ head height, $15.16 \mathrm{~cm}$ chest width, $19.94 \mathrm{~cm}$ chest inside, $34.25 \mathrm{~cm}$ shoulder height, chest circumference $33.49 \mathrm{~cm}$, body length $34.36 \mathrm{~cm}$, cannon circumference $6.31 \mathrm{~cm}$ and body size increase between age and head length is $0.056 \mathrm{~cm}$.
\end{abstract}

Keywords: Age, Body Size Increase, Local Goat, Pre Weaning

\begin{abstract}
ABSTRAK
Tujuan penelitian ini untuk mengetahui uluran-ukuran tubuh kambing lokal betina umur pra-sapih yang di pelihara secara tradisional. Penelitian ini telah dilaksanakan di Kecamatan Kabila Bone dibulan November- Desember 2018, Sebanyak 30 ekor kambing umur 1 (satu) minggu dijadikan obyek dalam penelitian. Materi penelitian adalah kambing lokal umur pra umur 1 minggu sampai 10 minggu sebanyak 30 ekor. Penelitian ini menggunakan metode survei. Penenetuan sampel dalam populasi menggunakan purposive sampling dan pengambilan data berdasarkan accidental sampling. Data yang diperoleh dianalisis dengan menghitung mean, standar deviasi, koefisien variasi, persamaan regresi, dan laju pertumbuhan antara umur dan ukuran tubuh. Berdasarkan hasil statistik diperoleh nilai rata-rata panjang kepala 8,62 cm, lebar kepala 6,92 cm, tinggi kepala 9,47 cm, lebar dada 15,16 cm, lebar dada 19,94 $\mathrm{cm}$, tinggi bahu $34,25 \mathrm{~cm}$, lingkar dada $33,49 \mathrm{~cm}$, panjang badan $34,36 \mathrm{~cm}$. , lingkar kanon $6.31 \mathrm{~cm}$ dan pertambahan ukuran tubuh antara umur dan panjang kepala $0.056 \mathrm{~cm}$
\end{abstract}

Kata kunci : Kambing lokal, Ukuran tubuh, Prasapih

Cara Mengutip (APA Citation Style)

Tagoi K,Y., Ilham F, dan Laya N,K., 2020 Analisis Morfometrik Ukuran Tubuh Kambing Lokal Umur Pra Sapih Yang Di Pelihara Secara Tradisional, Jambura Journal of Animal Science, 3(1), 38-45

(C) 2020 - Tagoi K, Y., Ilham F, dan Laya N,K., Under the license CC BY-SA 4.0 


\section{PENDAHULUAN}

Kambing Kacang atau kambing merupakan sumberdaya genetic local, Kambing ini dipelihara oleh masyarakat sebagai usaha sampingan (tabungan) hingga usaha skala beser. Ternak ini memiliki keunggulan yakni kemampuan adaptasi terhadap keterbatasan pakan, reproduksi yang tinggi dan tahan terhadap penyakit. (Ilham, F., dkk 2014). Menurtut Tunnisa (2013) kambing kacang adalah kambing lokal yang mempunyai daya adaptasi dilahan tandus seperti perbukitan, dengan kondisi pakan yang kurang, dan memiliki ketahanan tubuh yang kuat trerhadap penyakit. Ternak kambing juga merupakan sumber genetik yang khas untuk digunakan dalam perbaikan bangsabangsa melalui persilangan, lebih produktif dengan biaya yang sangat rendah, mendukung keragaman pangan, pertanian dan budaya, dan lebih efektif dalam mencapai tujuan keamanan lokal

Populasi ternak kambing di Kabupaten Bone Bolango tahun 2018 khususnya di Kecamatan Kabila Bone adalah 934 ekor (BPS, 2018) dan secara fenotipik sebagian besar sekilas terlihat memiliki ciri yang dimiliki oleh kambing kacang dan sebagian kecil kambing PE. Ternak-ternak kambing ini telah dipelihara masyarakat setempat secara turun temurun sehingga menghasilkan puluhan generasi, beradaptasi dengan lingkungan setempat, dan beberapa diantaranya memiliki karakteristik khas yang hanya dimiliki oleh ternak tersebut, Untuk menggambarkan seekor ternak yang memiliki cirri khas, dapat dilihat dari sifat kualitatif dan kuantitatif seekor ternak.

Beberapa penelitian mengungkapkan pertumbuhan kambing kacang membentuk kurva sigmoid, melalui persamaan $\mathrm{y}=-0,00215 \mathrm{x} 2+0,61764 \mathrm{x}+$ 6,91315 ( Abadi T, dkk 2013), adanya perbedaaan ukuran tubuh antara kambing betina dan jantan berbeda dan bergantung dari cara pemeliharaan (Azmidaryanti, R. dkk. 2017), dilaporkan juga oleh Laya, N. K. (2018) Terdapat hubungan yang kuat antara bobot badan dengan produksi susu kambing PE dengan nilai korelasi sebesar 0,691, dengan nilai koefisien korelasi mendekati +1 , persamaan regresi bobot badan dengan produksi susu kambing PE adalah $\mathrm{Y}=0,316+0,001 \mathrm{X}+\mathrm{e}$, sedangkan Pertumbuhan pra sapih di pengaruhi oleh musim kemarau dan penghujan (Nasution, S. A. D. D. A. T, dkk, 2010)

Pentingnya pengukuran ukuran tubuh, menaksir bobot badan, pada kambing lokal merupakan upaya menggali informasi penting dari ternak tersebut, Hasil pengukuran dapat dijadikan sebagai bahan utama informasi dalam pengembangan produktifitas dari ternak tersebut, dibidang pemuliaan ternak merupakan informasi dasar dalam peningkatan mutu genetic dari kambing lokal. Pengukuran dapat dilakukan sebelum sapih, setelah sapi atau pada umur dewasa kelamin. Penelitian ini bertujuan untuk mengetahui morfometrik kambing lokal umur pra sapih yang dipelihara secara tradisional.

\section{METODOLOGI PENELITIAN}

Penelitian ini telah dilaksanakan di Kecamatan Kabila Bone dibulan NovemberDesember 2018, Sebanyak 30 ekor kambing umur 1 (satu) minggu dijadikan obyek dalam penelitian. Penentuan lokasi dan Jumlah sampel dalam populasi menggunakan metode Sampling Purposive (Sugiono,2011). dan pengambilan sampel dilokasi dengan cara sampling Insidental. Pengukuran dilakukan pada kambing umur seminggudan diulang setiap minggu selam 10 minggu. Pengukuran menggunakan tongkat ukur dan pita ukur. Teknik Pengukuran ukuran tubuh kambing dilakukan pada keadaan ternak kambing berdiri dalam keadaan posis sempurna seperti pada gambar 1 . 


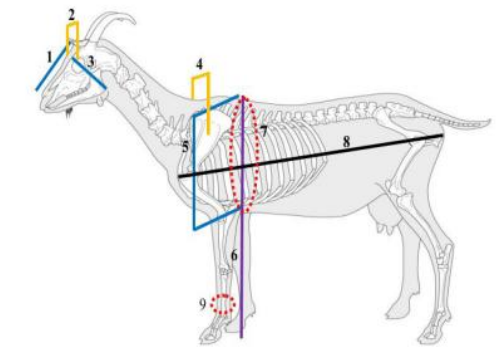

Gambar 1. Ukuran-Ukuran Tubuh

Keterangan:

1. Panjang kepala

2. Lebar kepala

3. Tinggi Kepala

4. Lebar dada

5. Dalam dada

6.Tinggi pundak

7. Lingkar dada

8. Panjang badan

9. Lingkar kaki canon kaki kiri depan

Pengukuran tubuh meliputi ukuranukuran tubuh :

a. Kepala

- Panjang kepala: jarak antara titik kepala sampai titik posterior tengkorak di ukur dengan mistar ukur (cm).

- Lebar kepala : jarak antara titik penonjolan tengkorak paling luar kiri dan kanan di ukur dengan kaliper $(\mathrm{cm})$

- Tinggi kepala : jarak antara titik dorsal tengkorak sampai titik lateral rahang terendah diukur dengan kaliper (cm).

b. Badan

- Lebar dada : jarak antara bagian tengah tulang dada kiri dan kanan diukur dengan kaliper (cm).

- Dalam Dada : diukur antara titik tertinggi pundak dan tulang dada, diukur di belakang siku

- Tinggi pundak diukur dari bagian tertinggi pundak ketanah mengikuti garis tegak lurus dengan menggunakan tongkat ukur.

- Lingkar dada diukur dalam satuan cm yang diambil dengan cara mengikuti lingkaran dada/tubuh tepat didekat scapula atau kaki depan bagian belakang (belakang siku).

- Panjang badan : jarak garis lurus dari tepi depan luar tulang scapula sampai dengan benjolan tulang tapis (os ischium), di ukur dengan tongkat ukur (cm).

- Lingkar cannon : diukur melingkar di tengah-tengah tulang pipa kaki depan dan belakang sebelah kiri diukur dengan pita ukur (cm).

\section{Analisis}

Data dianalisa secara deskriptif dan disajikan dalam bentuk rataan hitung, simpangan baku dan koefisien variasi. (Sudjana. 1996) :

a. Nilai rataan Pengamatan

Keterangan:

$$
\bar{X}=\sqrt{\sum \frac{X i}{n}}
$$

$\bar{X}=$ Nilai pengamatan atau nilai rata-rata sampel $\sum=$ Penjumlahan

$X_{i}=$ Nilai pengamatan ke-i

$\mathrm{N}=$ Jumlah sampel

b. Simpangan baku atau standar deviasi

Keterangan :

$$
S=\frac{\sqrt{(X i-\bar{X})^{2}}}{(n-1}
$$

$\bar{X}=$ Nilai pengamatan atau rata-rata sampel

$\Sigma=$ Penjumlahan

$\mathrm{X}_{\mathrm{i}}=$ Nilai pengamatan $\mathrm{ke}-\mathrm{i}$

$\mathrm{n}=$ Jumlah sampel

$\mathrm{S}=$ Standar deviasi atau simpangan baku

c. Koefisien variasi (KV)

Rumus koefisien variasi adalah :

$$
\mathrm{KV}=\frac{\mathrm{S}}{\overline{\mathrm{X}}} X 100 \%
$$

Analisis regresi linier sederhana di gunakan dalam penelitian ini sesuai yang disarankan oleh Laya, N. K. (2018) Rumus: 
Keterangan:

$$
\mathrm{Y}=\mathrm{a}+\mathrm{bX}
$$

$\mathrm{Y}=$ Umur

$X=$ Ukuran Tubuh

$\mathrm{a}=$ Konstanta (nilai $\mathrm{Y}^{\prime}$ apabila $\mathrm{X}=0$ )

$\mathrm{b}=$ Koefisien regresi

\section{HASIL DAN PEMBAHASAN Deskripsi Lokasi Penelitian}

Kecamatan Kabila Bone merupakan salah satu dari 17 kecamatan yang ada di Kabupaten Bone Bolango.Luas Kecamatan Kabila Bone secara keseluruhan adalah $143,51^{2} \mathrm{~km}$, Berdasarkan posisi geografisnya, Kecamatan Kabila Bone memiliki batas Tabel 1. Jumlah Desa di Kecamataan Kabila Bone

\begin{tabular}{|c|c|c|c|c|}
\hline No & Desa & Populasi Kambing & Luas $\left(\mathrm{Km}^{2}\right)$ & $(\%)$ \\
\hline 1 & Huangobotu & 45 & 19,43 & 13,54 \\
\hline 2 & Molutabu & 28 & 18,03 & 12,56 \\
\hline 3 & Oluhuta & 100 & 19,44 & 13,55 \\
\hline 4 & Botubarani & 53 & 9,65 & 6,72 \\
\hline 5 & Biluango & 170 & 10,56 & 7,36 \\
\hline 6 & Modelomo & 82 & 12,47 & 8,69 \\
\hline 7 & Botutonuo & 91 & 15,21 & 10,60 \\
\hline 8 & Olele & 309 & 29,50 & 20,56 \\
\hline 9 & Bintalahe & 56 & 9,21 & 6,42 \\
\hline
\end{tabular}

Sumber : BP3K Kecamatan Kabila Bone, 2017

\section{Karakteristik Manajemen Pemeliharaan}

Berdasarkan hasil pengamatan sistem pemeliharaan yang diterapkan peternak kambing lokal di Kecamatan Kabila Bone sebagian besar adalah semi intensif yaitu siang dilepas diluar kandang dan malam baru dikandangkan, dan sebagian kecil dengan cara dilepas terus diluar kandang. Anak kambing umur pra sapih sepenuhnya masih menyusui pada induknya, kemana induk berjalan mencari makan maka anaknya tetap bersamanya.

Model kandang dan sistem perkandangan yang dimiliki peternak umumnya masih sangat sederhana bahkan beberapa responden tidak memiliki kandang sebagai tempat melindungi ternak. Sebagian besar responden yang memiliki kandang dilokasi pengamatan menempatkan kambing lokal yang dimiliki di halaman rumah yang telah dikelilingi batas: Utara - Kecamatan Botupingge; Selatan - Teluk Tomini; Barat - Kecamatan Kota Timur (Kota Gorontalo); Timur Kecamatan Bone Pantai.

Berdasarkan data Balai Penyuluhan Pertanian Perikanan dan Kehutanan (BP3K) setempat hingga tahun 2017 jumlah desa yang ada di kecamatan Kabila Bone adalah 9 desa, dimana populasi terbanyak adalah Desa Olele dengan jumlah populasi 309 ekor. Lokasi pengamatan untuk pertambahan ukuran tubuh kambing lokal di Kecamatan Kabila Bone adalah semua desa yang ada di Kecamatan Kabila Bone. Populasi ternak masing-masing Desa tahun 2017 
Jenis pakan yang diberikan pada kambing saat berada dikandang sebagian besar adalah rumput dan daun-daunan, namun sistem pemberian pakan yang dilakukan tidak ditentukan baik waktu dan jumlahnya. Sumber pakan untuk kambing remaja dan telah dewasa dan sudah pernah beranak adalah bersumber dari rumput liar. Rumput liar dan legume pohon. Rumput liar banyak tumbuh dilahan pekarangan, lahan yang tidak dimanfaatkan atau lahan kosong dan di wilayah perbukitan. Beberapa peternak juga memberikan makanan lainnya dari sisa dapur seperti kulit pisang dan sayur sayuran yang tidak digunakan lagi. Pakan untuk kambing pra sapih adalah bergantung dari dari ketersediaan rumput liar dan menyusui dari induknya, peternak menyediakan pakan untuk ternak kambing tidak rutin. Pakan yang diberi oleh peternak adalah kulit pisang dan sayur sayuran dan legume pohon yang tersedia di sekitar kandang. Peran induk dari sangat utama dalam memelihara anaknya, Keberadaan induk kambing yang mengajak anaknya untuk mencari sendiri pakan yang dikonsumsi. Menurut Laya N.K, et al (2020). Pemeliharaan semi intensif, ternak dipelihara dengan cara digembalakan, diikat dalam luasan padang pengembalan dan dimalam hari ternak di pindahkan kedalam kandang.

\section{Ukuran Tubuh}

Ukuran tubuh pada penelitian ini diperoleh dengan mengukur bagian-bagian tubuh cempe sejak umur 1 minggu sampai umur 10 minggu. Ukuran tubuh yang di ukur meliputi panjang kepala, lebar kepala, tinggi kepala, lebar kepala, dalam dada, tinggi pundak, lingkar dada, panjang badan dan lingkar canon.Menurut Nilai rata- rata, ukuran tubuh selama $10 \mathrm{minggu}$ dapat dilihat pada Gambar 2.
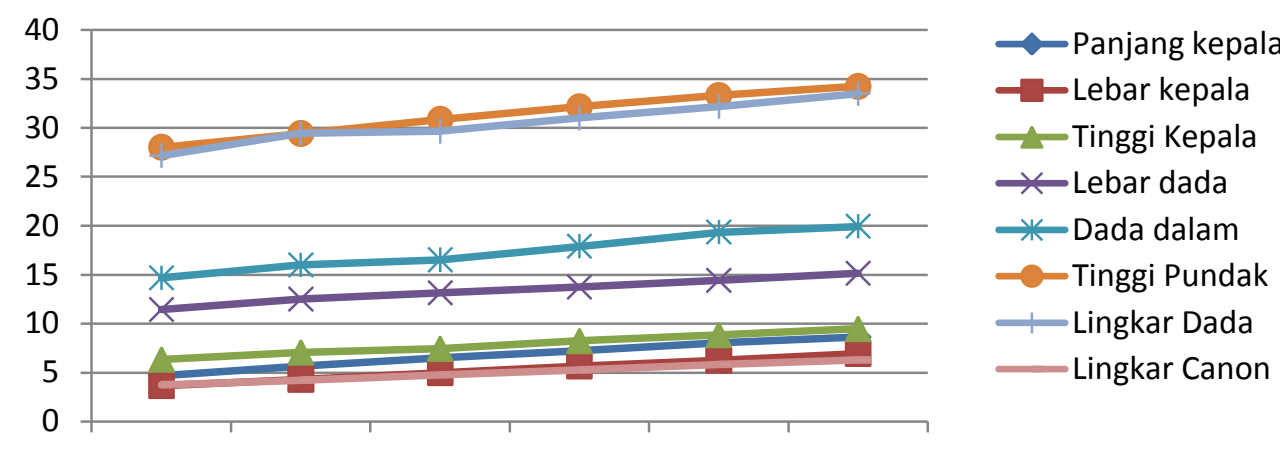

1 Minggu 2 Minggu 4 Minggu 6 Minggu 8 Minggu10 Minggu

Gambar 2. kurva pertambahan ukuran tubuh kambing lokal setiap 2 minggu-umur 10 minggu.

Berdasarkan Gambar 2. Rataan Ukuran-ukuran tubuh kambing lokal umur pra sapih diperoleh nilai rataan panjang kepala yaitu pada awal pengukuran umur 1 minggu adalah 4,69 dan di akhir pengukuran umur 10 minggu adalah 8,62 $\mathrm{cm}$. Rataan lebar kepala pada awal pengukuran umur 1 minggu adalah $3,67 \mathrm{~cm}$ dan diakhir pengukuran umur 10 minggu adalah 6,92 cm. Rataan Tinggi tengkorak pada awal pengukuran umur 1 minggu adalah $6,35 \mathrm{~cm}$, dan diakhir pengukuran umur 10 minggu adalah 9,47 cm. Rataan lebar dada pada awal pengukuran umur 1 minggu adalah 11,45 cm, dan diakhir pengukuran umur 10 minggu adalah 15,16 cm. Rataan dalam dada pada awal pengukuran umur 1 minggu adalah 14,69 $\mathrm{cm}$, dan diakhir pengukuran umur 10 minggu adalah 19,94 cm. Rataan tinggi pundak pada awal pengukuran umur 1 minggu adalah 28,03 cm, dan diakhir 
pengukuran umur 10 minggu adalah 34,25 $\mathrm{cm}$. Rataan lingkar dada pada awal pengukuran adalah 27,16 cm, dan diakhir pengukuran umur 10 minggu $33,49 \mathrm{~cm}$. Rataan panjang badan pada awal pengukuran umur 1 minggu adalah 27,83 $\mathrm{cm}$, dan diakhir pengukuran umur 10 minggu 34,36 cm. Rataan lingkar canon pada awal pengukuran umur 1 minggu adalah $3,76 \mathrm{~cm}$, dan diakhir pengukuran umur 10 minggu adalah 6,31 cm. Ukuranukuran tubuh kambing lokal mengalami peningkatan sesuai dengan peningkatan um urnya.

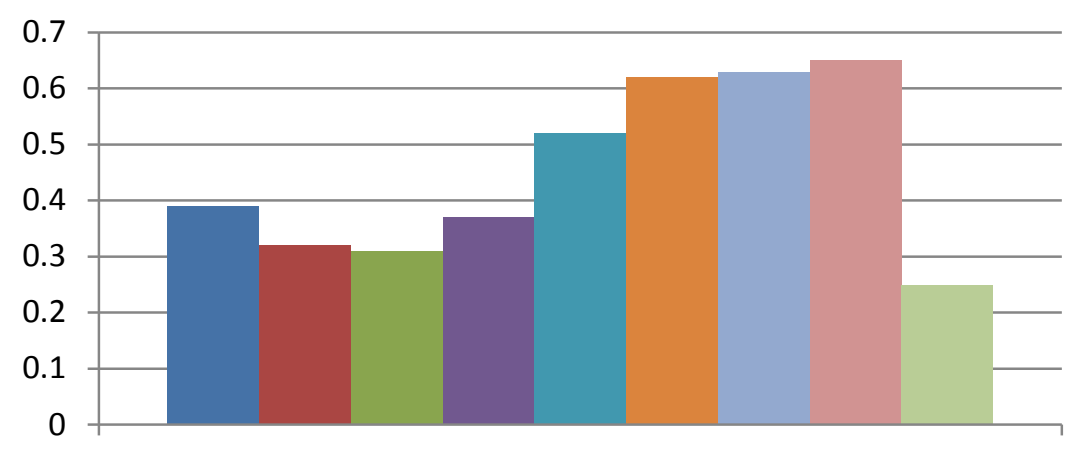

Rataan laju pertumbuhan Ukuran-Ukuran Tubuh

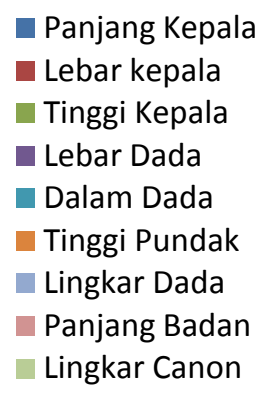

Panjang Kepala

Tinggi Kepala

- Lebar Dada

- Dalam Dada

Tinggi Pundak

Panjang Badan

Lingkar Canon

Gambar 3. laju pertambahan ukuran tubuh per/1 minggu kambing lokal pra sapih

Berdasarkan gambar 3. laju pertambahan ukuran tubuh per/1 minggu kambing lokal di Kecamatan Kabila Bone pada panjang kepala adalah 0,39 $\mathrm{cm}$, lebar kepala $0,32 \mathrm{~cm}$, tinggi kepala $0,31 \mathrm{~cm}$, lingkar canon $0,25 \mathrm{~cm}$, lebar dada $0,37 \mathrm{~cm}$, dalam dada $0,52 \mathrm{~cm}$, tinggi pundak $0,62 \mathrm{~cm}$, lingkar dada $0,63 \mathrm{~cm}$, panjang badan 0,65 $\mathrm{cm}$, penelitian ini berbeda dengan penelitian Hikaya, (2018), yaitu laju pertambahan ukuran tubuh pada lingkar dada adalah 0,50 cm, lebar dada 0,42 cm, dalam dada $0,47 \mathrm{~cm}$, panjang badan 0,49 $\mathrm{cm}$, dan pada tinggi pundak 0,52 cm. Semakin bertambah umur kambing maka ukuran tubuh juga semakin besar. Hal ini disebabkan karena ukuran tulang semakin bertambah. Peningkatan ukuran-ukuran tubuh ini disebabkan oleh pertumbuhan otot dan tulang yang semakin bertambah. Pertambahan ukuran tubuh seiring dengan berlalunya waktu terlihat jelas pada anak kambing dari berumur 1 minggu hingga mencapai 10 minggu. Namun laju pertumbuhannya tidak seragam pada setiap ukuran bagian tubuh. Menurut Davendra dan Burns (1994), pada dasarnya seekor ternak akan mengalami perubahan dimensi tubuh yang diakibatkan oleh sistem pemeliharaan, perubahan musim, dan jenis kelamin ternak. Pertumbuhan mempunyai tahap-tahap yang cepat dan lambat, tahap cepat terjadi saat ternak belum dewasa kelamin dan tahap lambat terjadi pada saat dewasa tubuh tercapai (Sampuma dan Suthan 2010).

\section{Regresi Umur Dan Ukuran Tubuh}

Analisis regresi dimaksudkan untuk menguji arah hubungan variabel-variabel independen terhadap variabel dependen. Variabel independen adalah ukuran tubuh berupa panjang kepala, lebar kepala, tinggi kepala, lebar dada, dalam dada, tinggi pundak, lingkar dada, panjang badan, dan lingkar canon, sedangkan variabel dependen adalah umur tubuh cempe pra sapih. Hasil analisis regresi disajikan pada tabel 4. 
Tabel 4 Persamaan regresi antara ukuran tubuh dan umur ternak pra sapih

\begin{tabular}{|c|c|c|c|c|}
\hline \multirow[t]{2}{*}{ No } & \multicolumn{2}{|c|}{ Variabel } & \multirow{2}{*}{$\begin{array}{c}\text { Persamaan Regresi } \\
\text { Ukuran Tubuh dan Umur }\end{array}$} & \multirow[t]{2}{*}{ Determinasi $\left(\mathrm{R}^{2}\right)$} \\
\hline & Ukuran Tubuh (Y) & Umur $(X)$ & & \\
\hline 1 & Panjang Kepala & 1-10 minggu & $Y=4,67+0,41 \cdot X$ & 78.8 \\
\hline 2 & Lebar Kepala & & $Y=3,54+0,34 . X$ & 75.10 \\
\hline 3 & Tinggi Kepala & & $Y=6,28+0,32 \cdot X$ & 70.35 \\
\hline 4 & Lingkar Canon & & $Y=3,63+0,37 \cdot X$ & 78.67 \\
\hline 5 & Dalam Dada & & $Y=14,46+0,57 \cdot X$ & 80,20 \\
\hline 6 & Tinggi Pundak & & $Y=27,46+0,66 . X$ & 85,70 \\
\hline 7 & Lingkar Dada & & $Y=26,86+0,67 \cdot X$ & 89,6 \\
\hline 8 & Panjang Badan & & $Y=27,32+0,70 \cdot X$ & 90,20 \\
\hline 9 & Lebar Dada & & $Y=11,49+0,27 \cdot X$ & 60.10 \\
\hline
\end{tabular}

Berdasarkan tabel 4 ukuran tubuh dapat dipengaruhi oleh umur pada ternak lokal umur pra sapih akan mengikuti pola pertumbuhan, artinya bahwa setiap kenaikan umur 1 minggu maka ukuran tubuh meningkat sebesar nilai $x$ dan nilai rataan $\mathrm{R}^{2}$ dari ukuran tubuh sebesar 78.52, sehingga diawal pertumbuhan kambing, faktor umur mempengaruhi kenaikan bobot badan anak kambing (cempe) sebesar $78.52 \%$

Kurnianto, E., \& Purbowati, E. (2013). Variabel ukuran-ukuran tubuh yang digunakan dalam persamaan untuk menduga bobot badan kambing Kacang adalah panjang muka, panjang telinga,

\section{DAFTAR PUSTAKA}

Abadi, T., Lestari, C. S., \& Purbowati, E. (2015). Pola Pertumbuhan Bobot Badan Kambing Kacang Betina Di Kabupaten Grobogan (Growth Pattern of Body Weight of Female Kacang Goats in Grobogan Regency). Animal Agriculture Journal, 4(1), 93-97.

Azmidaryanti, R., Misrianti, R., \& Siregar, S. (2017).

Perbandingan Morfometrik Kambing Kacang yang Dipelihara Secara Semi Intensif dan Intensif di Kabupaten Kampar, Provinsi Riau. Jurnal Ilmu Produksi dan lingkar dada, lebar dada, panjang badan, tinggi pundak, lebar pinggul dan panjang kaki belakang. Pola pertumbuhan kambing kacang jantan di Kabupaten Konawe Selatan cenderung meningkat seiring bertambahnya umur dan 94,8 \% faktor umur bisa menentukan bobot badan kambing kacang jantan di Konawe Selatan

\section{KESIMPULAN}

Ukuran tubuh kambing lokal umur 1-10 minggu yang dipelihara secara tradisional meningkat seiring dengan bertambahnya umur ternak. Dan faktor umur dapat menentukan pertambahan ukuran tubuh sebesar $78.52 \%$

Teknologi Hasil Peternakan, 5(2), 84-88.

BPS Kabupaten Bone Bolango. 2018. Kabupaten Bone Bolango dalam angka 2016. Badan Pusat Statistik Kabupaten Bone Bolango

Devendra, C. dan M, Burns.1994. Produksi Kambing di Daerah Tropis. Penerbit ITB.Bandung.

Ilham, F. 2014. "Keragaman fenotipe Kambing Lokal Kabupaten Bone Bolango". Dalam Prosidding Seminar Nasionl Dan Workshop Optimalisasi Sumber Daya Lokal 
pada Peternakan Rakyat Berbasai Teknologi-1 di UNHAS, Makassar. 9-10 )ktober 2014.

Kurnianto, E., \& Purbowati, E. (2013). Hubungan antara ukuran-ukuran tubuh dengan bobot badan pada kambing Kacang di Kabupaten Grobogan, Jawa Tengah. Animal Agriculture Journal, 2(1), 28-34.

Nasution, S. A. D. D. A. T., Mahmilia, F., \& Doloksaribu, M. (2010). Pengaruh musim terhadap pertumbuhan kambing kacang prasapih di stasiun percobaan loka penelitian Kambing Potong Sei Putih. In Prosiding Seminar Nasiomal Teknologi Peternakan dan Venteriner (pp. 3-4).

Laya N. K, Ibrahim Dj., Dako, S., Datau F, 2020. Analysis Of The Size And Body Weight Characteristic Of Ongole Cattle That Are Kept With Intensive And SemiIntensive System. Journal of Seybold Report. ISSN NO: 15339211, VOLUME 15 ISSUE 8, 2020. 2737-2747.

https://m.box.com/shared_item /https\%3A\%2F\%2Fapp.box.com
\%2Fs\%2Fe9v9r0pjgzp7ztsev8vhpi $\mathrm{y} 05 \mathrm{khc} 7 \mathrm{x} 31$

Laya, N. K. (2018). Hubungan Bobot Badan Dan Produksi Susu Kammbig Peranakan Etawa (PE). Jambura Journal of Animal Science, 1(1), 1318.

Sampuma, I. P. dan I. K. Suatha. 2010. Pertumbuhan Alometri Sabrani. M., Levine, J.M., 1993. Pendekatan Sistem Pertanian Untuk Produksi Ruminansia Kecil. di : Tomaszewska, M. W., Mastika, I.M., Djajanegara A., Gardiners, Wiadarya T. Produksi Kambing dan Domba di Indonesia. Penerbit Universitas Sebelas Maret Solo.

Sudjana. 1996. Metode Statistik. Bandung. Tarsito.

Sugiyono. 2011. Metode Penelitian Pendidikan Pendekatan Kuantitatif, kualitatif, dan RED. Bandung: Alfabeta

Tunnisa, R. I. D. H. A. (2013). Keragaman gen IGF-1 pada populasi kambing Kacang di Kabupaten Jeneponto. Skripsi. Universitas Hasanuddin. Makasar. 